\title{
Particle size selection, feeding rates and growth dynamics of marine planktonic oligotrichous ciliates (Ciliophora: Oligotrichina)
}

\author{
Per R. Jonsson
}

Tjärnö Marine Biological Laboratory, PI. 2781, S-452 00 Strömstad, Sweden

\begin{abstract}
Particle size selection and functional response were studied for 3 marine oligotrichous ciliates. Each species showed a distinct size spectrum of ingested particles. The optimal particle size was $2.1 \mu \mathrm{m}$ for Strombidium vestitum, $7.9 \mu \mathrm{m}$ for Strombidium reticulatum and $9.7 \mu \mathrm{m}$ for Lohmanniella spiralis. None of the species could effectively retain $1 \mu \mathrm{m}$ particles. The functional response (ingestion rate as function of particle concentration) could be fitted to a hyperbolic function with no apparent feeding threshold at low particle concentrations. Maximum clearing rates for the 3 species ranged from 0.52 to $26 \mu \mathrm{J} \mathrm{h}^{-1}$. Video recordings of feeding ciliates revealed that particle capture of oligotrichous ciliates is similar to other investigated polyhymenophorans. $S$. reticulatum and $L$. spiralis were isolated from seawater to start laboratory cultures and the numerical response (growth rate as function of food concentration) was studied. Maximum growth rate was 0.036 and $0.044 \mathrm{~h}^{-1}$ for $S$. reticulatum and $L$. spiralis respectively. Yield (gross growth efficiency) was over $40 \%$ (based on volume) for both species. The present study shows that the tested oligotrichous ciliates feed in the size range of autotrophic and heterotrophic microflagellates, but that they are incapable of effective ingestion of bacterioplankton.
\end{abstract}

\section{INTRODUCTION}

It has been increasingly apparent that very small organisms constitute an important role in marine pelagic food webs and that a substantial part of primary production in the water-column is due to photoautotrophs less than $3 \mu \mathrm{m}$, including microflagellates and cyanobacteria (Johnson \& Sieburth 1979, 1982, Murphy \& Haugen 1985). Several studies also show that aquatic photoautotrophs release a significant portion of photosynthate as dissolved organic carbon (DOC) (see review by Larsson \& Hagström 1982). The exudate release appears to be rapidly assimilated by bacterioplankton which reconvert this DOC fraction to particulate carbon, and recent studies reveal that bacterial production in the water-column is greater than previously believed, that is, up to 5 to $20 \%$ of primary production (Fuhrman \& Azam 1982, Larsson \& Hagström 1982). Thus the major part of particulate carbon production originates from organisms in the size range of a few microns or less. Food particles within this size range are mostly unavailable to metazoan zooplankton, notably copepods (Nival \& Nival 1976). This calls for a revision of our view on the lower trophic levels in the traditional pelagic food chain as consisting of large diatoms and dinoflagellates preyed upon by mesozooplankton, mainly copepods.

In the search for 'missing links' in an extended food web, much interest has focused on the assemblage of organisms operationally defined by Sieburth (1979) as nanozooplankton ( 2 to $20 \mu \mathrm{m}$ ) and microzooplankton (20 to $200 \mu \mathrm{m}$ ). In particular the significance of heterotrophic flagellates (Fenchel 1982d) and planktonic ciliates has been proposed (e.g. Margalef 1967, Beers \& Stewart 1969, Heinbokel \& Beers 1979, Smetacek 1981). Due to inappropriate sampling techniques planktonic ciliates were almost overlooked in routine zooplankton samples until the early seventies. The few reliable reports available of ciliate biomass, e.g. Rassoulzadegan (1977), Smetacek (1981) and Revelante \& Gilmartin (1983), all indicate that planktonic ciliates make up a substantial part of zooplankton biomass. Considering the rapid metabolism per unit weight of ciliates (Klekowski 1981, Fenchel \& Finlay 1983), these biomass assessments suggest an important role for ciliates in the pelagic food web. Previous work on food uptake and growth dynamics has concentrated on tintinnids (suborder Tintinnina), which are a com- 
mon component of microzooplankton (e.g. Heinbokel 1978a, Rassoulzadegan \& Etienne 1981, Stoecker et al. 1983). Their possession of a lorica makes them sturdy and well represented in plankton samples. Careful sampling techniques, e.g. Dale \& Burkill (1982), have revealed that ciliates other than tintinnids generally dominate the plankton. The 'naked' and thus fragile oligotrichous ciliates, belonging to the same order (Oligotrichida) as the tintinnids, seem to be most abundant (Rassoulzadegan 1977).

Few studies treat planktonic oligotrichous ciliates. Apart from a few studies documenting their abundance (Rassoulzadegan 1977, Smetacek 1981) only 6 physiological and ecological studies of planktonic oligotrichous ciliates exist (Grim \& Halcrow 1979, Rassoulzadegan 1982, Børsheim 1984, Gifford 1985, Scott 1985, Sheldon et al. 1986). More information on marine oligotrichous ciliates is needed where particle size selection and efficiency of capture are studied with various methods and for several species. Studies of growth rates as functions of food concentration (numerical response) are also necessary in order to evaluate to what extent food concentration is limiting in nature. In this paper I present results of a study on functional response and particle size selection measured directly as ingested latex beads or microalgae. In addition parameter estimates of the numerical.responses for 2 species of oligotrichous ciliates are offered together with estimates of gross growth efficiency.

\section{MATERIALS AND METHODS}

Material. The study is based on 3 species of planktonic ciliates representing the 2 most abundant families, Strombidiidae and Strobilidiidae, of the suborder Oligotrichina. Almost no recent published work exists on the taxonomy of oligotrichous ciliates and the most complete studies remain that of Leegaard (1915) and the compiled work of Kahl (1932). There is great need for a treatment of these ciliates using modern methods of ciliate taxonomy such as protargol staining and electron microscopy. Against this background I made observations with scanning electron microscope (SEM) and impregnated the studied ciliates with protargol according to Tuffrau (1967). Specimens for SEM were fixed in osmic acid $(2 \% \mathrm{w} / \mathrm{v})$ and prepared according to Watson et al. (1980). On the basis of existing taxonomic literature, I have identified the 3 studied species as Strombidium reticulatum (Leegaard), Strombidium vestitum (Leegaard) and Lohmaniniella spiralis Leegaard.

Preparation of laboratory cultures. Strombidium reticulatum and Lohmanniella spiralis were isolated from surface seawater samples from the Kosterfjord on the west coast of Sweden. From these seawater sam- ples I also isolated a prasinophycean microflagellate, Pyramimonas sp. Schmarda, which was used as a single food source for the isolated ciliates. Pyramimonas sp. was grown in enriched seawater using the f/2-medium (Guillard 1975). The ciliate cultures were maintained in plastic microwells $(3 \mathrm{ml})$ and multidisks $(15 \mathrm{ml})$ (cell and tissue containers from A/S Nunc, Denmark) containing filtered and autoclaved seawater with added Pyramimonas sp. Growth of $L$. spiralis required the addition of EDTA (approximately $10 \mu \mathrm{M}$ ). No effort was made to free the cultures from bacteria. However, successful growth of $L$. spiralis required that the concentration of bacteria was kept low. Bacterial growth was inhibited by the addition of penicillin ( 50

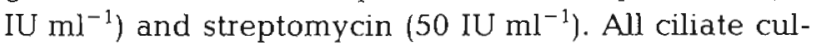
tures were kept at $12^{\circ} \mathrm{C}$ in a $16: 8 \mathrm{~h}$ light:dark cycle. At weekly intervals, a few ciliates were transferred to fresh medium with exponentially growing Pyramimonas sp. A major obstacle in this study of marine oligotrichous ciliates has been the difficulty of culturing them under controlled conditions. Quite recently Gifford (1985) described the first successful attempt to culture oligotrichous ciliates (Strombidium spp.) isolated from the marine pelagial. According to Gifford growth depended critically on the concentrations of trace metals and EDTA, a chelating agent. Culturing of Strombidium spp. and $L$. spiralis in this study support the findings of Gifford (1985) that metal contamination can be highly detrimental to survival and growth. Another initial culture problem was to find suitable food sources. Although ingested, several laboratory strains of autotrophic and heterotrophic flagellates and species of diatoms did not support growth. The Pyramimonas sp. isolated from water samples with growing oligotrichous ciliates gave rapid and reliable growth of $S$. reticulatum and L. spiralis.

Uptake experiments. To study particle uptake, I used suspensions of latex beads (Dow Chemical Company, USA, and Coulter Electronics Ltd., Luton, England). The following diameters were used: $1.01,2.11,2.87$, $5.7,6.4,9.7,14.4$ and $19.1 \mu \mathrm{m}$. In some experiments I used monocultures of Pavlova lutheri (Droop) Green, Pyramimonas sp., Tetraselmis suecica (Kylin) Butcher and Saccharomyces cerevisiae Hansen (equivalent sphere diameter of $4.9,5.7,7.9$ and $4.5 \mu \mathrm{m}$, respectively). Cell sizes were measured with an Elzone 80xy particle counter (Particle Data Inc., Elmhurst, USA) with 128 channels. Field populations of all 3 ciliate species from the Kosterfjord (Sweden) and from the Limfjord (Denmark) as well as laboratory cultures of Strombidium reticulatum and Lohmanniella spiralis were used for studies on particle uptake. Seawater temperatures at sampling were from 12 to $16^{\circ} \mathrm{C}$; experiments were carried out at $12^{\circ} \mathrm{C}$. When ciliates are placed in suspensions of particles a linear uptake with 


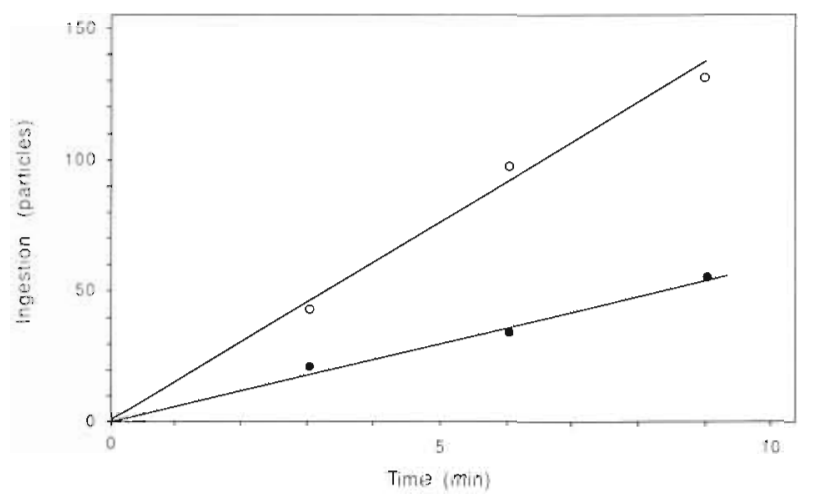

Fig. 1. Lohmanniella spiralis. Ingestion of $5.7 \mu \mathrm{m}$ latex beads as a function of time at 2 different particle concentrations: $5 \times 10^{4} ;(0) 3 \times 10^{5}$ particles $\mathrm{ml}^{-1}$

time is found (Fig. 1). In the experiments with ciliates collected in the field, I added latex beads or cultured microalgae to fresh water samples. After 2 to $20 \mathrm{~min}$ of incubation, depending on the concentration of added particles, I picked up individual cells with a capillary pipette and transferred them to a drop of formalin $(10 \%)$. Under a compound microscope (Leitz Dialux 125 to $1250 \times$ ) I counted ingested latex beads or microalgae individually within each ciliate. Particle concentrations were measured with a haemocytometer $(2$ replicates) giving a standard error of about $\pm 5 \%$ of the mean or with an Elzone 80xy particle counter with a standard error of less than $\pm 2 \%$ of the mean. This method for estimating ingestion rate and clearing rate of field populations introduces an error due to naturally occurring particles in the sample. During the ingestion of a particle, the cytostome is blocked and a ciliate is unable to take up a new particle. At high natural particle concentrations, added latex beads or microalgae may therefore be outcompeted and clearing rates calculated from ingestion of added particles will be underestimated. This situation is analogous to competitive inhibition of enzymes and the impact of natural particles can be calculated accordingly (Lehninger 1975). In all experiments concentrations of naturally occurring particles were always sufficiently low to give a maximum underestimate of uptake rate of only $3 \%$. Another source of error may arise from a differential selection of latex as compared to natural food particles. Much evidence shows that ciliates feeding on small particles do not discriminate between different particles on the basis of properties other than size and shape (Fenchel 1980a,b). Since the studied oligotrichous ciliates could feed on relatively large food items I tested possible selection for properties other than mechanical ones. Clearing rates of latex beads and of microalgae of approximately the same size and shape are compared in Table 1. L. spiralis and Strombidium vestitum revealed no significant dif-
Table 1. Comparison of clearing rates (mean $\pm 1 \mathrm{SE}$ ) between uptake experiments with latex beads and living particles. Values are given in $\mu \mathrm{l} \mathrm{h} \mathrm{h}^{-1}$

\begin{tabular}{|c|c|c|}
\hline Species & $\begin{array}{l}\text { Latex } \\
\text { beads }\end{array}$ & $\begin{array}{l}\text { Living } \\
\text { particles }\end{array}$ \\
\hline Lohmanniella spiralis ${ }^{1}$ & $11 \pm 1.0(5)^{\circ}$ & $9.9 \pm 0.8(4)$ \\
\hline Strombidium reticulatum ${ }^{2}$ & $1.7 \pm 0.2(64)$ & $2.6 \pm 0.3(26)$ \\
\hline Strombidium vestitum ${ }^{3}$ & $0.13 \pm 0.01$ & $0.13 \pm 0.01$ \\
\hline \multicolumn{3}{|c|}{$\begin{array}{l}{ }^{1} 9.7 \mu \mathrm{m} \text { latex beads and Tetraselmis suecica } \\
{ }^{2} 6.4 \mu \mathrm{m} \text { latex beads and Pavlova Iutheri } \\
{ }^{3} 2.87 \mu \mathrm{m} \text { latex beads and Saccharomyces cerevisiae } \\
\cdot \text {. }\end{array}$} \\
\hline
\end{tabular}

ferences. S. reticulatum showed greater variance in clearing rate between individuals for latex beads than for microalgae. Since the distribution of clearing rates among individual ciliates was skewed to the right, a greater variance resulted in a lower average. Maximum clearing rates for individual $S$. reticulatum, however, were not significantly different for ciliates feeding on latex beads as compared to those feeding on microalgae. The slight difference in clearing rates between latex beads and comparable microalgae may partly be explained by differences in shape and size distribution. However, the possibility exists that chemical stimuli from food particles influence ingestion rate. In all experiments I selected the quartile of individuals showing the highest feeding rates, since this study is mainly concerned with the potential capabilities of oligotrichous ciliates. The variance in food ingestion between individuals is interesting in itself and requires further studies.

In addition to field populations I used laboratory cultures of Lohmanniella spiralis and Strombidium reticulatum for some studies of particle uptake. In these experiments, cultured ciliates were transferred to vials containing culture medium with low concentrations ( $<5000$ cells ml ${ }^{-1}$ ) of Pyramimonas sp. which was used as food. After an acclimation period of $12 \mathrm{~h}$, latex beads or microalgae were added and the ingestion rate was then measured as described above. Temperature was $12^{\circ} \mathrm{C}$ in all experiments. Concentrations of added particles were always much greater than that of Pyramimonas sp. I found no significant difference in clearing rate between field and culture populations (Table 2).

These results from the uptake experiments were used to evaluate the form of the functional response for all studied particles that resulted in significant uptake. Using SAS statistical program NLIN-regression (SAS Institute Inc., Cary, USA) ingestion rate as function of environmental particle concentration could be closely fitted to a hyperbolic function of the form:

$$
\mathrm{U}=\mathrm{U}_{\mathrm{m}} \mathrm{C}_{\mathrm{p}} /\left(\mathrm{K}+\mathrm{C}_{\mathrm{p}}\right)
$$


Table 2. Comparison of clearing rates (mean $\pm 1 \mathrm{SE}$ ) between laboratory cultures and field populations. Values are given in $\mu \mathrm{l} \mathrm{h}^{-1}$

\begin{tabular}{lcc|}
\hline \multicolumn{1}{c}{ Species } & Culture & $\begin{array}{c}\text { Field } \\
\text { population }\end{array}$ \\
\hline $\begin{array}{l}\text { Lohmanniella spiralis } \\
\text { Strombidium reticulatum }{ }^{2}\end{array}$ & $20 \pm 1.9(6)^{\circ}$ & $24 \pm 2.6(6)$ \\
& $2.6 \pm 0.3(26)$ & $3.0 \pm 0.4(29)$ \\
${ }^{1}$ Uptake measured with $9.7 \mu$ m latex & \\
${ }^{2}$ Uptake measured with & Pavlova lutheri and Py- \\
ramimonas sp. & & \\
- Sample size & & \\
\hline
\end{tabular}

where $U=$ ingestion rate (numbers of particles per unit time); $\mathrm{U}_{\mathrm{m}}=$ maximum ingestion rate $\mathrm{C}_{\mathrm{p}}=$ particle concentration; $\mathrm{K}=$ a half-saturation constant. $\mathrm{A}$ useful measure to compare efficiency of uptake between different particle sizes is the maximum volume of water cleared of particles per unit time. The hyperbolic fit gives maximum clearing rates as $\mathrm{U}_{\mathrm{m}} / \mathrm{K}$. The non-linear regression procedure produces error statistics for the parameter estimates. Since the ratio of the 2 parameters describing the hyperbolic fit are used to calculate maximum clearing rates it should be possible to calculate error estimates of the clearing rates presented in Table 3 . The 2 parameters are, however, strongly correlated which makes error estimation difficult. If instead the uptake data are analysed with power regression (Statgraphics STSC, Inc., Maryland, USA), the slopes have an average standard error of $\pm 10 \%$ of the mean. If errors of particle concentration determination and timing of incubation are added, estimates of maximum clearing rates would have a standard error of about $\pm 20 \%$ of the mean.

Recordings of feeding ciliates. As an independent method for studying dynamics of food uptake, I recorded live ciliates with a video camera fitted to a compound (Olympus BH-2) or a dissecting microscope (Wild M5 with dark field). The video taperecorder (Panasonic NV-180) allowed sequences with feeding ciliates to be played back frame by frame, obtaining 25 still pictures per second. By tracking particles which moved along flow lines round the membranelle zone of active ciliates I could reconstruct the flow field. The water flow through the membranelles was then calculated and compared to clearing rates found in the experiments with particle uptake. Since water flows generated by ciliates are characterized by low Reynolds number with viscous forces predominating, solid surfaces will affect flow lines even at a considerable distance from the ciliate. To reduce this wall effect from slides and coverslips, I used a 'hanging drop' when recording Strombidium reticulatum. Lohmanniella spiralis could be recorded in a $10 \mathrm{ml}$ chamber using a dissecting microscope $(50 \times)$. This completely eliminated distortions of the flow field.

Growth experiments. Growth rates as function of food concentration were measured on laboratory cultures of Strombidium reticulatum and Lohmanniella spiralis. In all experiments, Pyramimonas sp. was used as the only food source. In principle organisms never attain balanced growth in batch cultures since food resources are continuously removed. However, for the growth rate experiments presented here, I used combinations of number of ciliates, amount of food and incubation times so that the initial food concentration was reduced only about $10 \%$ during the experiments. Experimental suspensions were prepared from exponentially growing Pyramimonas sp. and the GF/C filtered seawater was either autoclaved or, in the experiments with $L$. spiralis, treated with penicillin $\left(50 \mathrm{IU} \mathrm{ml}^{-1}\right)$ and streptomycin $\left(50 \mathrm{IU} \mathrm{ml}^{-1}\right)$. Food concentrations were determined with an Elzone particle counter giving a standard error of less than $\pm 2 \%$ of the mean. In order to avoid unpredictable effects due to the previous growth conditions ciliates were allowed to grow at the experimental food concentration for at least $2 \mathrm{~d}$ before the measurements started. In a typical experiment 2 ciliates were transferred from stock cultures to each vial in a multidisk $(15 \mathrm{ml})$ containing a series of food concentrations (see Fig. 7), and incubated in the dark at $12^{\circ} \mathrm{C}$ for between $48 \mathrm{~h}$ and $2 \mathrm{wk}$ depending on growth rate. Ciliates were transferred to fresh medium and food every $24 \mathrm{~h}$ to ensure near constant food concentration and quality. Three to 5 replicates were set up for each food concentration. Shaking was avoided since it is apparently detrimental to both $S$. reticulatum and $L$. spiralis. Nevertheless, Pyramimonas sp. showed an even distribution in the experimental vials. In the multidisks it was easy to follow the increase in numbers of ciliates and 3 to 4 generations were followed. From measurements of population numbers and time, I calculated growth rate per hour assuming exponential growth. Growth rate as function of food concentration was fitted to a hyperbolic function using SAS statistical program NLINregression (SAS Institute Inc., Cary, USA).

Yield (gross growth efficiency) was estimated for Lohmanniella spiralis and Strombidium reticulatum in batch cultures. Two or 3 replicates were set up for each food concentration. When ciliates had depleted all food they were counted and fixed in formalin and cell volumes were estimated from linear dimensions. To compensate for shrinkage due to fixation and deviations from assumed cell shapes, I measured living cell volume of dense cultures with an Elzone particle counter. From the same cultures I sampled ciliates which were fixed in formalin and measured under the microscope. In this way I established correction factors 
for estimating living cell volume from measurements of fixed ciliates. Since shape changes slightly with increasing size I calculated correction factors for 2 different cell sizes using starving and fast growing cultures. Correction factors ranged from 1.5 to 1.7 for $S$. reticulatum and 0.77 to 0.92 for $L$. spiralis. The cell volume of Pyramimonas sp. was determined with an Elzone particle counter to be $97 \mu \mathrm{m}^{3}$. Gross growth efficiency could then be expressed as per cent volume of new ciliates per volume of ingested algae.

\section{RESULTS}

\section{Uptake experiments}

Particle uptake as function of environmental particle concentration could be closely fitted to a hyperbolic function. Examples are shown in Fig. $2 \& 3$. Table 3 summarizes estimates of maximum clearing rates (volume of water per unit time) for the 3 species. None of the uptake experiments showed any evidence of a feeding threshold at low particle concentrations. Each species shows a characteristic size spectrum of particles which are retained and ingested. Fig. 4 shows maximum clearing rates as function of particle size for the 3 studied species expressed in units of ciliate volumes per hour. For the 3 species maximum clearing rate is correlated with both ciliate size and optimum particle size.

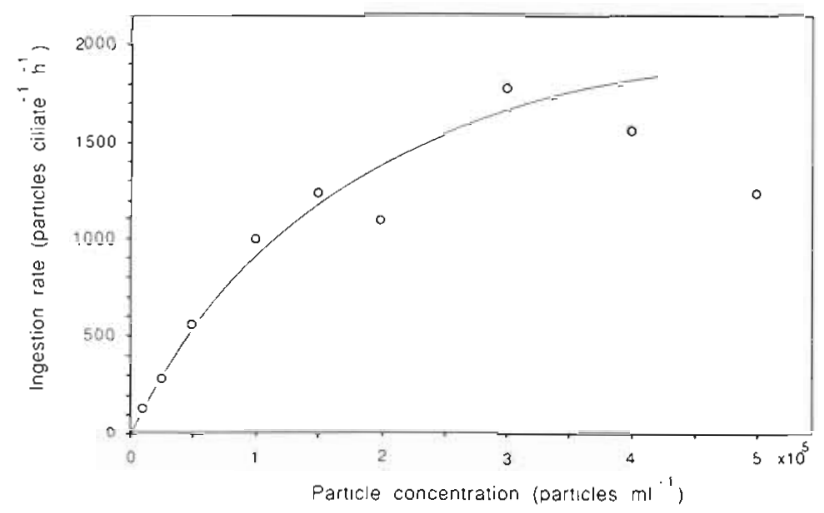

Fig. 2. Lohmanniella spiralis. Ingestion rate of $5.7 \mu \mathrm{m}$ latex. beads as a function of particle concentration. The curve represents a numerically fitted hyperbolic function

\section{Feeding currents and particle capture}

Fig. $5 \& 6$ show some streamlines generated by Lohmanniella spiralis and Strombidium reticulatum. Measurements of living and fixed ciliates showed that L. spiralis have an average free space between adjacent membranelles ranging from $2 \mu \mathrm{m}$ in the basal region to $4 \mu \mathrm{m}$ in the upper part. In $S$. reticulatum feeding currents pass between membranelles with free spaces ranging from $1.2 \mu \mathrm{m}$ to $4.4 \mu \mathrm{m}$. With only 25 frames $s^{-1}$ the video recordings could not in detail track particles inside the peristome. The transport of captured particles to the cytostome can, however, be

Table 3. Maximum clearing rates of different sized particles for the 3 studied oligotrichous ciliates

\begin{tabular}{|c|c|c|c|}
\hline Species & Particle & Size $(\mu \mathrm{m})$ & Clearing rate $\left(\mu l h^{-1}\right)$ \\
\hline \multicolumn{4}{|l|}{ Lohmanniella spiralis } \\
\hline & Latex & 1.11 & 0 \\
\hline & Latex & 2.11 & 1.6 \\
\hline & Latex & 2.87 & 3.4 \\
\hline & Latex & 5.7 & 13.4 \\
\hline & Latex & 9.7 & 26 \\
\hline & Latex & 14.4 & 18 \\
\hline & Latex & 19.1 & 0 \\
\hline \multicolumn{4}{|c|}{ Strombidium reticulatum } \\
\hline & Latex & 1.11 & 0.24 \\
\hline & Latex & 2.11 & 1.1 \\
\hline & Latex & 2.87 & 1.2 \\
\hline & Pavlova lutheri & 4.9 & 2.6 \\
\hline & Pyramimonas sp. & 5.7 & 3.1 \\
\hline & Latex & 6.4 & 1.7 \\
\hline & Tetraselmis suecica & 7.9 & 3.5 \\
\hline & Latex & 9.7 & 0 \\
\hline \multicolumn{4}{|l|}{ Strombidium vestitum } \\
\hline & Latex & 1.11 & 0.11 \\
\hline & Latex & 2.11 & 0.52 \\
\hline & Latex & 2.87 & 0.27 \\
\hline & Latex & 6.4 & 0.20 \\
\hline & Latex & 9.7 & 0 \\
\hline
\end{tabular}




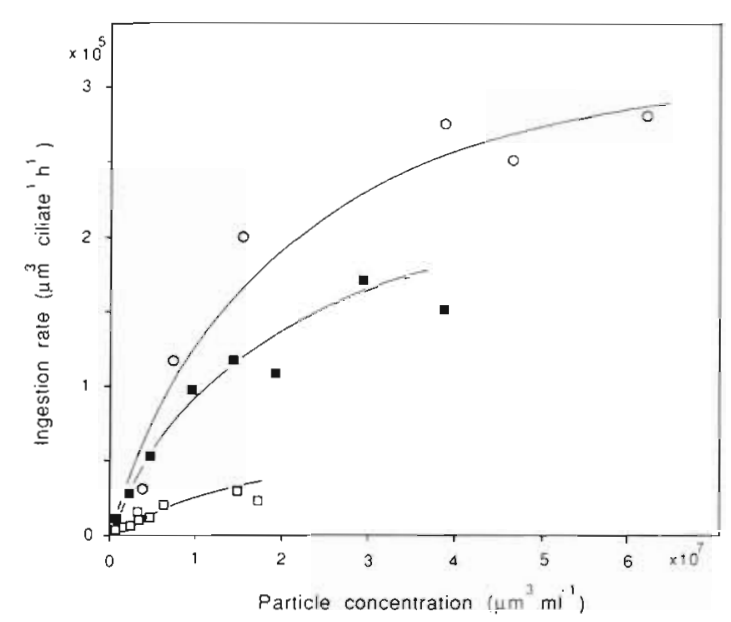

Fig. 3. Lohmanniella spiralis. Ingestion rate, expressed as $\mu \mathrm{m}^{3} \mathrm{~h}^{-1}$, of 3 sizes of latex beads as a function of particle concentration, expressed as $\mu \mathrm{m}^{3} \mathrm{ml}^{-1}$. The curves represent numerically fitted hyperbolic functions. (o) $14.4 \mu \mathrm{m}$; $5.7 \mu \mathrm{m}_{i}$ (ㅁ) $2.87 \mu \mathrm{m}$

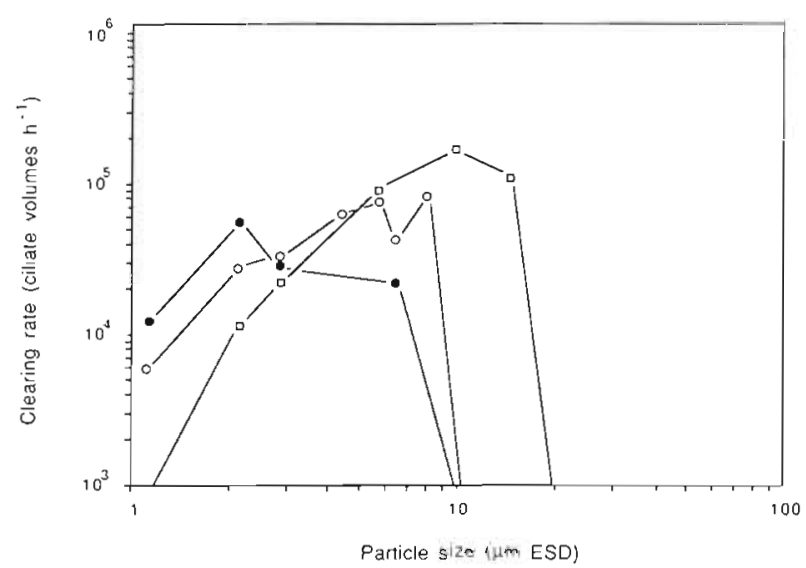

Fig. 4. Maximum clearing rate (in multiples of ciliates own volume per hour) as function of particle size for the 3 studied species of oligotrichous ciliates. ( $\square$ ) Lohmanniella spiralis; (O) Strombidium reticulatum; (•) Strombidium vestitum

inferred from the arrangement of the membranelles. The anterior views of the oral areas (Fig. $5 \mathrm{~b} \& 6 \mathrm{~b}$ ) show that in both $L$. spiralis and $S$. reticulatum membranelles, going from the center, are orientated so that water propelled out from the peristome has a clockwise velocity component. This component (hatched arrows in Fig. 5b \& 6b) may help in transporting particles to the cytostome. Moreover, as the cytostome is in the lower end of the spiraling peristome floor (Fig. 5a \& 6a) and water is pumped out of the peristome all the way down to the cytostome, a flow in the direction of the cytostome should result. Distally the membranelles are twisted clockwise (seen from posterior) which results in a rotational component of the velocity field of the flow (Fig. 5b \& 6 b) and this hydrodynamical momentum leads to a slow (20 to $30 \mathrm{rpm})$ counter-clockwise rotation (seen from posterior).
Measurements of current velocities and estimates of filtering area render it possible to calculate the volume of water processed per unit time which can be compared with clearing rates found in the uptake experiments. The filtering area of Lohmanniella spiralis measured from photographs of living and fixed ciliates is about $3.7 \times 10^{3} \mu^{2}$. Video recordings give a current velocity through the membranelles of $1.6 \times 10^{3} \mu \mathrm{m}$ $\mathrm{s}^{-1}$. This yields a water transport rate of $2.1 \times 10^{-2}$ $\mathrm{ml} \mathrm{h}^{-1}$ which is close to the maximum clearing rate which was found to be $2.6 \times 10^{-2} \mathrm{ml} \mathrm{h}^{-1}$. In the case of Strombidium reticulatum the calculation is more approximate since the membranelles in the cytostome region are smaller with decreasing free space (Fig. 6). If the measured current velocity of $1.3 \times 10^{3} \mathrm{um} \mathrm{s}^{-1}$ applies to all membranelles and the filtering area is

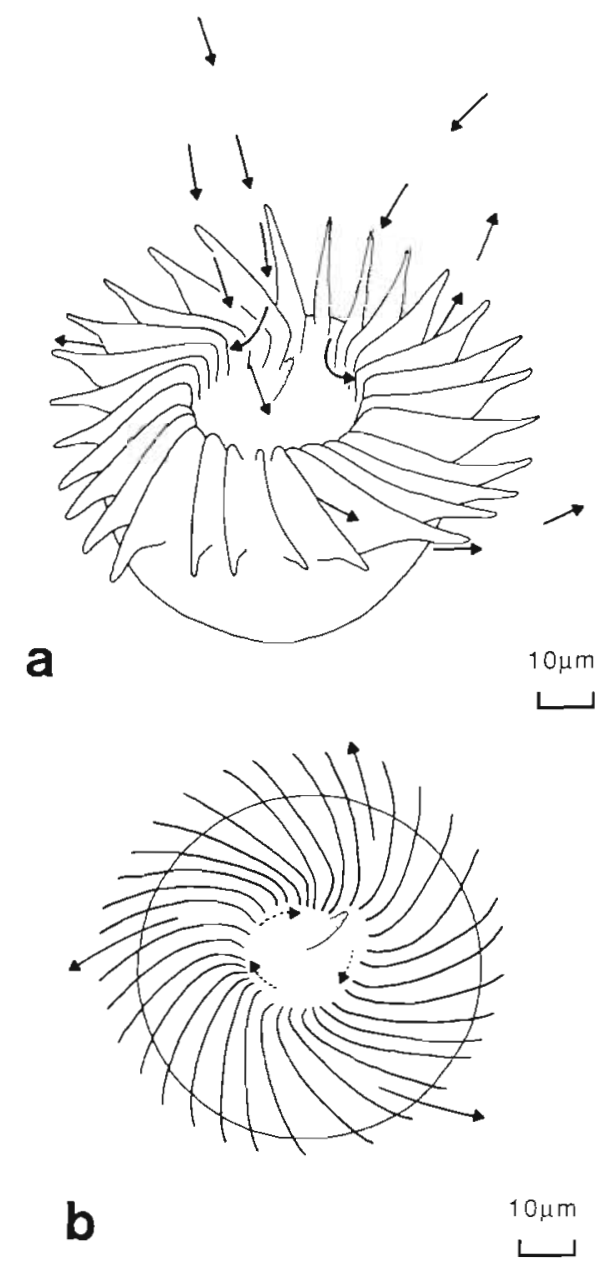

Fig. 5. Lohmanniella spiralis. Semi-diagrammatic drawings. (a) Oral area viewed obliquely from anterior. Solid arrows illustrate some streamlines of the water-flow field formed by the membranelle zone. (b) Oral area viewed straight from anterior. Solid arrows mark streamlines and dashed arrows inside the peristome represent a current component perpendicular to the membranelles 


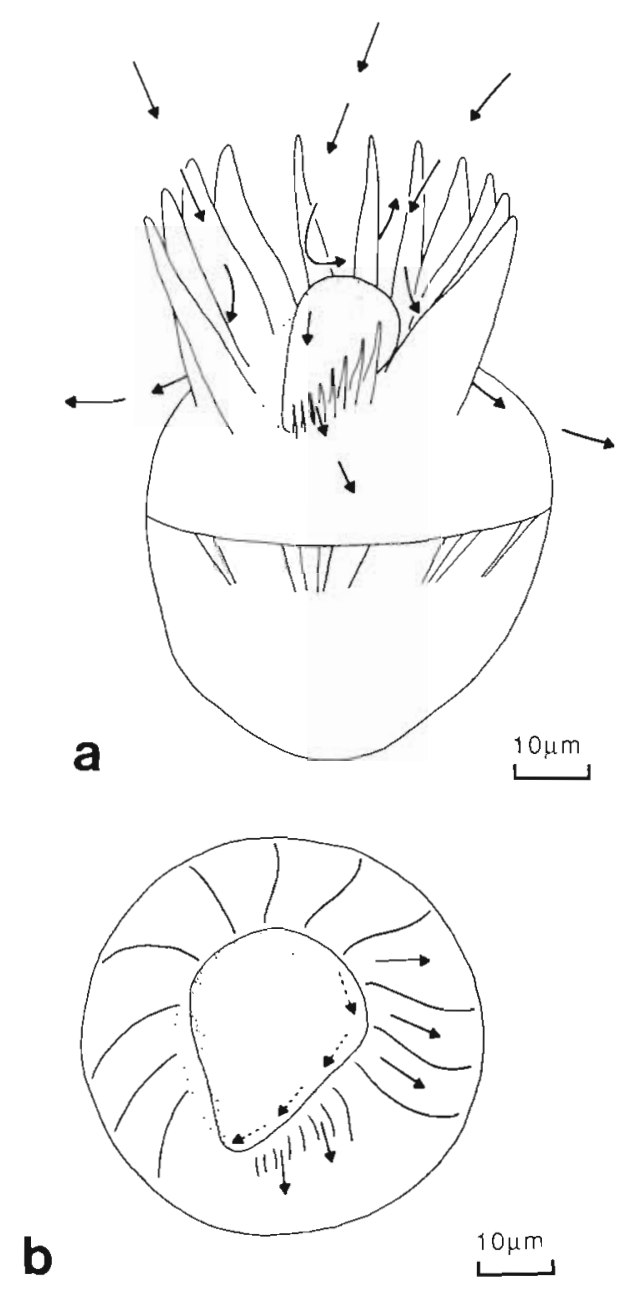

Fig. 6. Strombidium reticulatum. Semi-diagrammatic drawings. (a) Oral area viewed from side. Solid arrows illustrate some streamlines of the water-flow field formed by the membranelle zone. (b) Oral area straight from anterior. Solid arrows mark streamlines and dashed arrows inside the peristome represent a current component perpendicular to the membranelles

roughly $6.5 \times 10^{2} \mu \mathrm{m}^{2}$ (measured from SEM photographs) this yields a water transport rate of $3 \times 10^{-3}$ $\mathrm{ml} \mathrm{h}{ }^{-1}$ which is in good agreement with the uptake experiments where maximum clearing rate was found to be $3.5 \times 10^{-3} \mathrm{ml} \mathrm{h}^{-1}$. These calculations indicate that retention of optimal particles is close to $100 \%$.

\section{Growth experiments}

Exponential growth rates could in both cases be closely fitted to a hyperbolic function (Fig. 7). A maximum growth rate is approached as the food concentration increases. The maximum growth rate was $0.044 \mathrm{~h}^{-1}$ for Lohmanniella spiralis and $0.036 \mathrm{~h}^{-1}$ for Strombidium reticulatum. A lower threshold of about
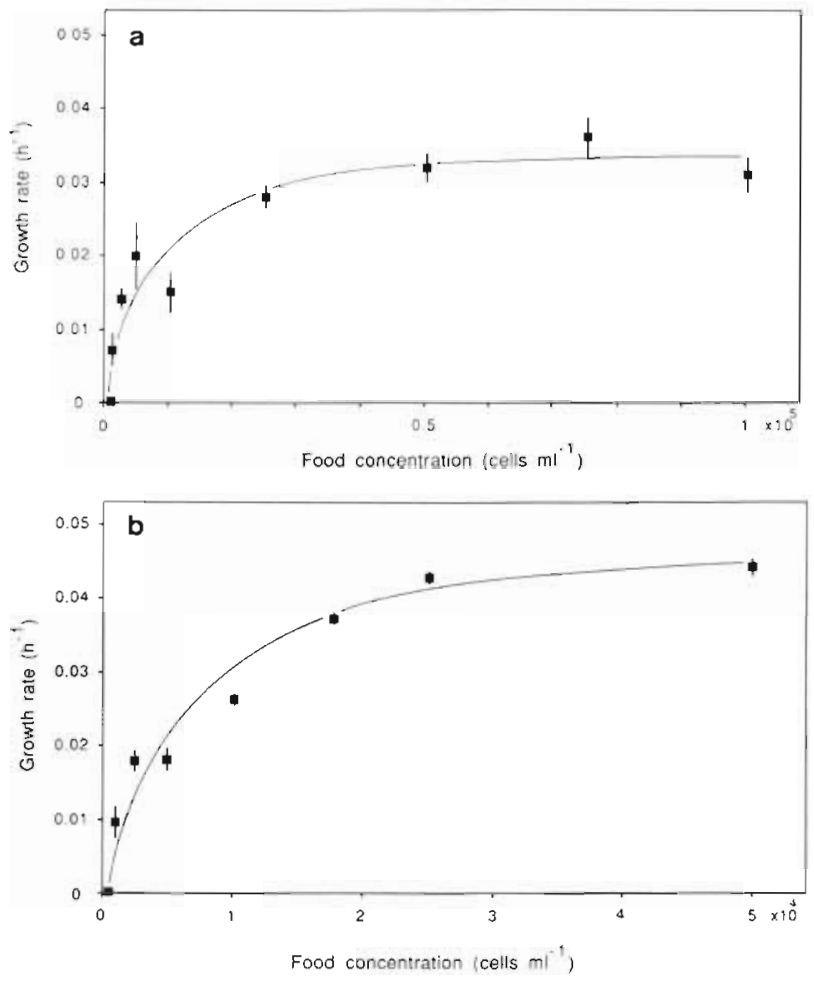

Fig. 7. Growth rate $(\mu)$ as function of food (Pyramimonas sp.) concentration $\left(C_{p}\right)$. Symbols represent treatment means \pm 1 $\mathrm{SE}$ and are numerically fitted to a hyperbolic function.

(a) Strombidium reticulatum; $\mu=\frac{0.035 \times\left(C_{p}-880\right)}{6300+\left(C_{p}-880\right)}$

(b) Lohmanniella spiralis; $\mu=\frac{0.049 \times\left(C_{p}-730\right)}{5400+\left(C_{p}-730\right)}$

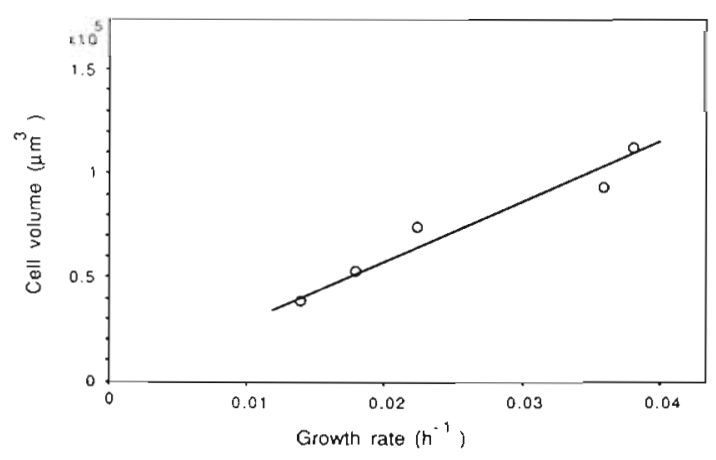

Fig. 8. Strombidium reticulatum. Cell volume as function of exponential growth rate

1000 Pyramimonas sp. $\mathrm{ml}^{-1}$ under which no growth occurred and with eventual mortality was found for both species. Cell volume in the experiments was proportional to growth rate (Fig. 8), but food concentrations above $2 \times 10^{5}$ cells $\mathrm{ml}^{-1}$ caused repeated stomatogenesis without cell division in $S$. reticulatum resulting in multi-mouthed giants.

Estimates of yield (gross growth efficiency) measured as volume of new ciliates per volume of ingested 

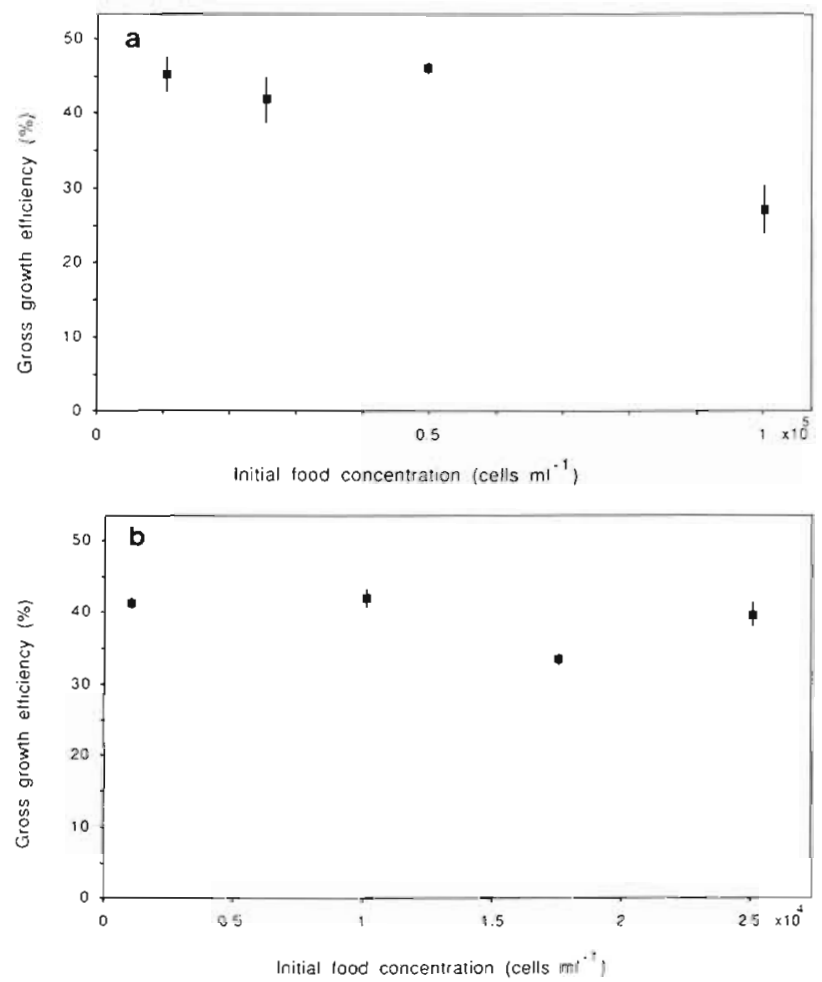

Fig. 9. Gross growth efficiency (GGE) as function of initial food (Pyramimonas sp.) concentration. GGE is expressed as \% volume of new ciliates per ingested volume of food. Symbols represent treatment means $\pm 1 \mathrm{SE}$. (a) Strombidium reticulatum; (b) Lohmanniella spiralis

food are shown in Fig. 9. Within the range of initial food concentrations used, gross growth efficiency was nearly constant with a tendency to decrease at very high food concentrations for Strombidium reticulatum. At lower food concentrations gross growth efficiency was slightly above $40 \%$ for both species.

\section{DISCUSSION}

\section{Functional response}

Ingestion rate as a function of particle concentration could in all experiments be closely fitted to a hyperbolic function. Fenchel (1980a) argued that this is a biologically sound description of the functional response of suspension feeders, assuming that a constant volume of water is processed per unit time and that the cytostome is blocked a finite time during phagocytosis of a particle. At high particle concentrations of the larger particles I found that ingestion rate decreased with time. Since, in this study, ingestion rates at high concentrations are based on experiments lasting a few minutes to avoid turnover of ingested particles, this will overestimate long-term ingestion rates. This effect may be caused by clogging of the filtration apparatus or when cell volume rather than the rate of food vacuole formation becomes limiting.

\section{Particle size selection}

The 3 studied oligotrichous ciliates select somewhat larger particles than previously investigated small polyhymenophorans (Fenchel 1980a, 1986). Compared to the present study Rassoulzadegan (1982) found similar results for Lohmanniella spiralis with the exception of a more effective retention of smaller particles (1.9 to $7.5 \mu \mathrm{m})$. Fenchel (1980b, 1986) gave strong evidence that the membranelle zone in polyhymenophoran ciliates acts as a sieve retaining particles of approximately the same size as the free space between adjacent membranelles. Morphological observations of distances between membranelles and studies of actively feeding $L$. spiralis and Strombidium reticulatum support the findings of Fenchel (1986). This explains why L. spiralis clear $5.7 \mu \mathrm{m}$ particles at about $50 \%$ of maximum clearing rate for $9.7 \mu \mathrm{m}$ particles, and why particles less than $2 \mu \mathrm{m}$ are not retained. The less welldefined size spectra found for Strombidium vestitum and $S$, reticulatum are probably due to the presence of closely spaced small membranelles in the cytostome region, which can account for the low ingestion rate of $1.1 \mu \mathrm{m}$ particles. None of the 3 species could effectively retain and ingest particles of $1.1 \mu \mathrm{m}$ even though $S$. vestitum cleared $1.1 \mu \mathrm{m}$ latex beads at the same rate as the bacterivorous Paramecium trichium Stokes which is of comparable size (Fenchel 1980a). The ability to retain and ingest large particles is set by the shape of the particles and the morphology of the oral area. I have observed that in both $L$. spiralis and in $S$. reticulatum large particles are retained by the membranelle sieve, but subsequently lost, possibly due to the inappropriate size or shape of the peristome or the cytostome. The ratio of the diameter of maximum particle size ingested and the diameter of the peristome is about 0.4 for all 3 species and similar to the ratio found in tintinnids (Spittler 1973, Heinbokel 1978b).The shape of food particles will influence ingestion rate and in this study all tested particles were approximately spherical. At least some species of Strombidium can ingest very long and narrow algae such as some diatoms and dinoflagellates (unpubl. obs.). The effect of particle shape on ingestion rate for most suspension feeders is yet unknown. In contrast to my own observations, Gifford (1985) found that Strombidium spp. ingested food particles bigger than the oral diameter and that even cannibalism occurred.

Are the studied oligotrichous ciliates feeding on small or large prey? Fenchel (1986) plotted the size of both filter-feeding and raptorial ciliates against prey 
size. The plot showed that if the length ratio of predator and prey exceeded 0.1 raptorial feeding is the most favourable mechanism and otherwise filter feeding is found. The oligotrichous ciliates in the present study all come somewhere in between these 2 categories and the ratio slightly exceeds 0.1 . When prey size becomes larger it may pay off to be more selective, which is observed in most large-prey eaters. However, this prediction should apply only when there is a substantial cost in handling a large food item. This does not seem to be the case with the ciliates in this study. All uptake experiments show that handling time per prey is very short compared to the expected encounter rate in nature. The longest handling time was found for Lohmanniella spiralis which needed 15 seconds to ingest $14.4 \mu \mathrm{m}$ particles. Even at a concentration of 1000 such particles per ml, which is rare in nature, only $9 \%$ of the encountered particles will be lost due to handling of an already captured particle. This implies that the oligotrichous ciliates in the present study do not necessarily benefit from an active prey selection. This may explain the uptake experiments where artificial particles and microflagellates were ingested at equal rates, even though the food items were of large size.

\section{Clearing rates}

Information on clearing rates for oligotrichous ciliates is sparse in the literature. For Lohmanniella spiralis fed on naturally occurring particles Rassoulzadegan (1982) presented clearing rates ranging from 2.3 to $8.9 \times 10^{-3} \mathrm{ml} \mathrm{h}^{-1}$ using an electronic particle counter where disappearance of natural particles was measured. Lessard \& Swift (1985) analysed uptake of radioisotope labelled natural particles and found a clearing rate of $4.3 \times 10^{-2} \mathrm{ml} \mathrm{h}^{-1}$ for Lohmanniella sp. The maximum clearing rate estimated from uptake experiments in the present study for $L$. spiralis was $2.6 \times 10^{-2} \mathrm{ml} \mathrm{h}^{-1}$. Scott (1985) reported a clearing rate for a Strombidium sp. grown in chemostat of $1.5 \times$ $10^{-3} \mathrm{ml} \mathrm{h}^{-1}$. The estimate seems somewhat low considering that the cell volume was about 10 times the volume of Strombidium reticulatum in this study which cleared optimum particles at a rate of $3.5 \times 10^{-3}$ $\mathrm{ml} \mathrm{h}^{-1}$. A possible cause may be that the concentration of food particles was very high in Scott's experiment resulting in lower clearing rates due to saturation of ingestion rate. In a recent paper Børsheim (1984) added latex beads to natural lake water containing a Strombidium sp. and counted ingested latex beads in the food vacuoles. For the 2 tested latex bead sizes, 0.57 and $1.04 \mu \mathrm{m}$, he calculated clearing rates between 2.6 and $9.0 \times 10^{-4} \mathrm{ml} \mathrm{h}^{-1}$ with the smaller particle being less efficiently ingested. The small particles used were probably of suboptimal sizes as discussed in Børsheim (1984) (cf. the rates of $2.4 \times 10^{-4} \mathrm{ml} \mathrm{h}^{-1}$ for $1.1 \mu \mathrm{m}$ particles found for $S$, reticulatum in the present study). More experiments are needed where particle size selection and clearing rates can be measured directly with uptake experiments, and this especially applies to very small oligotrichous ciliates (less than $20 \mu \mathrm{m}$ ) which are abundant in many areas.

How do clearing rates of oligotrichous ciliates compare with those of tintinnids? In Table 4 clearing rates for tintinnids from Heinbokel (1978a) and Verity (1985) are shown together with data on oligotrichous ciliates from the present study, all expressed in units of ciliate volumes per hour. Even though it is not known whether the tintinnids were fed optimal food particles, and while temperature differed between experiments, the data suggest that the 2 Strombidium species have lower volume specific clearing rates than the tintinnids and Lohmanniella spiralis. One possible explanation is that the Strombidium spp. have a zone with closer spaced membranelles resulting in greater resistance to water flow (Fenchel 1986).

Table 4. Clearing rates and cell volumes of tintinnid and oligatrichous ciliates

\begin{tabular}{|c|c|c|c|}
\hline \multirow[t]{2}{*}{ Species } & \multirow[t]{2}{*}{ Cell volume $\left(\mu \mathrm{m}^{3}\right)$} & \multicolumn{2}{|c|}{ Clearing rate } \\
\hline & & $\mu l h^{-1}$ & Cell vol. $\mathrm{h}^{-1}$ \\
\hline Tintinnopsis cf. acuminata ${ }^{1}$ & $1.1 \times 10^{4}$ & 2.8 & $2.5 \times 10^{5}$ \\
\hline Eutintinnus pectinis ${ }^{1}$ & $1.8 \times 10^{4}$ & 5 & $2.7 \times 10^{5}$ \\
\hline Tintinnopsis acuminata ${ }^{2}$ & $1.2 \times 10^{4}$ & 1.8 & $1.5 \times 10^{5}$ \\
\hline Tintinnopsis vasculum ${ }^{2}$ & $1.2 \times 10^{5}$ & 7.5 & $6.2 \times 10^{4}$ \\
\hline Lohmanniella spiralis ${ }^{3}$ & $1.5 \times 10^{5}$ & 26 & $1.8 \times 10^{5}$ \\
\hline Strombidium reticulatum ${ }^{3}$ & $4.0 \times 10^{4}$ & 3.5 & $8.8 \times 10^{4}$ \\
\hline Strombidium vestitum ${ }^{3}$ & $8.9 \times 10^{3}$ & 0.52 & $5.8 \times 10^{4}$ \\
\hline \multicolumn{4}{|c|}{${ }^{1}$ Heinbokel (1978a); experimental temperature $18^{\circ} \mathrm{C}$} \\
\hline \multicolumn{4}{|c|}{${ }^{2}$ Verity (1985); experimental temperature $15^{\circ} \mathrm{C}$} \\
\hline \multicolumn{4}{|c|}{${ }^{3}$ Present study; experimental temperature $12^{\circ} \mathrm{C}$} \\
\hline
\end{tabular}




\section{Food particle requirements}

The findings on clearing rates can be used to evaluate the minimum food concentration needed to sustain the basic energetic demands. The energetic demands of ciliates expressed as respiration of $\mathrm{O}_{2}$ per unit time have been reviewed by Fenchel \& Finlay (1983). Since respiration activity depends on growth rate and cell size, I have used values from the literature which correspond to the same cell sizes as Lohmanniella spiralis and Strombidium reticulatum and were obtained under non-growth conditions which may correspond to limiting food concentrations. It is also necessary to know with what efficiency food is assimilated. Stoecker (1984) presented assimilation efficiencies for Favella sp. Jörgensen averaging $71 \%$. Assimilation efficiency can also be calculated as the ratio of gross and net growth efficiency. If the gross growth efficiency of $45 \%$ found for $S$. reticulatum in the present study is divided by a net growth efficiency for growing protozoans of $67 \%$ based on theoretical reasoning (Fenchel \& Finlay 1983) this gives an assimilation efficiency of $67 \%$. I also assume that the respiratory quotient $R Q$ is unity and a conversion factor of 0.071 for volume to carbon (Fenchel \& Finlay 1983). With an $\mathrm{O}_{2}$ consumption of $9 \times 10^{-8} \mathrm{mg} \mathrm{O}_{2} \mathrm{~h}^{-1}$ cell $^{-1}$ and a maximum clearing rate of $3.5 \times 10^{-3} \mathrm{ml} \mathrm{h}^{-1} \mathrm{~S}$. reticulatum needs a minimum food concentration of $9.6 \mu \mathrm{g} \mathrm{Cl} \mathrm{Cl}^{-1}$. With a clearing rate of $3.0 \times 10^{-3} \mathrm{ml} \mathrm{h}^{-1}$ this corresponds to about 1600 Pyramimonas sp. $\mathrm{ml}^{-1}$ which is close to the concentration where growth ceased in the growth experiments shown in Fig. 7. Similar calculations for $L$. spiralis with an $\mathrm{O}_{2}$ consumption of $1.5 \times 10^{-7} \mathrm{mg} \mathrm{O} \mathrm{O}^{-1}$ cell $^{-1}$ and a maximum clearing rate of $2.6 \times 10^{-2} \mathrm{ml} \mathrm{h}^{-1}$ yield a limiting food concentration of $3.2 \mu \mathrm{g} \mathrm{Cl^{-1 }}$. With $L$. spiralis clearing Pyramimonas sp. at a rate of $1.3 \times$ $10^{-2} \mathrm{ml} \mathrm{h}^{-1}$, this would correspond to 900 Pyramimonas sp. $\mathrm{ml}^{-1}$ which is close to the lower limit of growth shown in Fig. 7.

\section{Growth of oligotrichous ciliates}

An important feature of planktonic life in temperate seas is the variable food supply where conditions change in time and space from abundance to starvation. The ability to change growth rate in response to food availability may be an adaptation to a heterogeneous environment (Fenchel 1982c). For this to be effective in Lohmanniella spiralis and Strombidium reticulatum the half-saturation constant in the numerical response experiments shown in Fig. 7 should be in the range of natural food concentrations. Detailed data on size-specific abundance of total nano- and micro- plankton are scarce in the literature but under favourable conditions heterotrophic flagellates may contribute approximately $10 \mu \mathrm{C} \mathrm{Cl}^{-1}$ (Fenchel 1982d) and nanophytoplankton regularly attain standing stocks of $100 \mu \mathrm{g} \mathrm{Cl}^{-1}$ in coastal waters (Burkill 1982). Halfsaturation constants in Fig. 7 are approximately $40 \mu \mathrm{g}$ $\mathrm{C}^{-1}$ (volume converted to carbon using a factor of 0.071 ) for both $L$. spiralis and $S$. reticulatum indicating that the range of growth rates found are realized in natural environments.

Gross growth efficiencies of Strombidium reticulatum and Lohmanniella spiralis (Fig. 9) are similar to the $39 \%$ (based on volume) for $L$. spiralis reported by Sheldon et al. (1986) but somewhat lower than Verity (1985) found for 2 tintinnids, 46 to $49 \%$ (based on carbon). Assuming an assimilation efficiency of about $70 \%$ (Stoecker 1984) these values are close to the theoretical net growth efficiency of $67 \%$ suggested in Fenchel \& Finlay (1983). Compiled data on growth efficiencies of invertebrates (Calow 1977, Conover 1978) indicate that planktonic ciliates grow at similar efficiencies as do many micrometazoans.

\section{Food web implications}

A hypothesis of a 'microbial loop' has been proposed to fill in the 'missing links' in the transfer of particulate carbon from very small producers to the bigger metazoan zooplankton (Azam et al. 1983). In a series of papers Fenchel $(1982 \mathrm{a}, \mathrm{b}, \mathrm{c}, \mathrm{d})$ showed the importance of heterotrophic microflagellates, mainly 3 to $7 \mu \mathrm{m}$ chrysomonads, as efficient predators on bacterioplankton. As an additional trophic level planktonic ciliates may be major predators on small autotrophic and heterotrophic flagellates. The impact oligotrichous and tintinnid ciliates have on the pelagic food web can be understood by combining laboratory experiments with in situ population densities. The present study shows that the 3 investigated species of oligotrichous ciliates feed on particles ranging from 1 to $15 \mu \mathrm{m}$. This covers the abundant autotrophic and heterotrophic flagellates but largely excludes the bacterioplankton. If clearing rates are multiplied by densities of oligotrichous ciliates found in Rassoulzadegan (1977), Smetacek (1981) and my own unpublished observations, estimates of the proportion of seawater cleared per day by the 3 species of oligotrichous ciliates are obtained. Very roughly, an average of 10 to $35 \%$ of the water is cleared by these species together per day, indicating that oligotrichous ciliates may be significant predators on heterotrophic and autotrophic flagellates. Recently much interest has focused on the ubiquitous coccoid cyanobacteria (Johnson \& Sieburth 1979). The size of these unicellular autotrophs is approximately $0.8 \mu \mathrm{m}$ 
and in coastal waters cyanobacteria may reach standing stocks of about $5 \times 10^{4} \mu^{3} \mathrm{ml}^{-1}$ (Murphy \& Haugen 1985). If the clearing rates of $1.1 \mu \mathrm{m}$ particles for Strombidium vestitum and Strombidium reticulatum are used (Table 3) the ingested volume of cyanobacteria is about 5 and $10 \mu \mathrm{m}^{3} \mathrm{~h}^{-1}$ ciliate $^{-1}$ respectively. This is considerably less than ingestion of heterotrophic flagellates alone which is 20 and $100 \mu \mathrm{m}^{3} \quad \mathrm{~h}^{-1}$ ciliate $^{-1}$ respectively, assuming a flagellate density of $3.7 \times 10^{4} \mathrm{um}^{3} \mathrm{ml}^{-1}$ (Fenchel 1982d). This indicates that cyanobacteria are of minor importance to the oligotrichous ciliates in the present study. The occurrence in seawater samples of smaller $(<20 \mu \mathrm{m})$ oligotrichous ciliates with ingested bacteria and cyanobacteria has been reported (Rassoulzadegan 1977, Sherr et al. 1986). Although no experimental study has yet tested the ability of small oligotrichous ciliates to grow on bacteria at the concentrations found
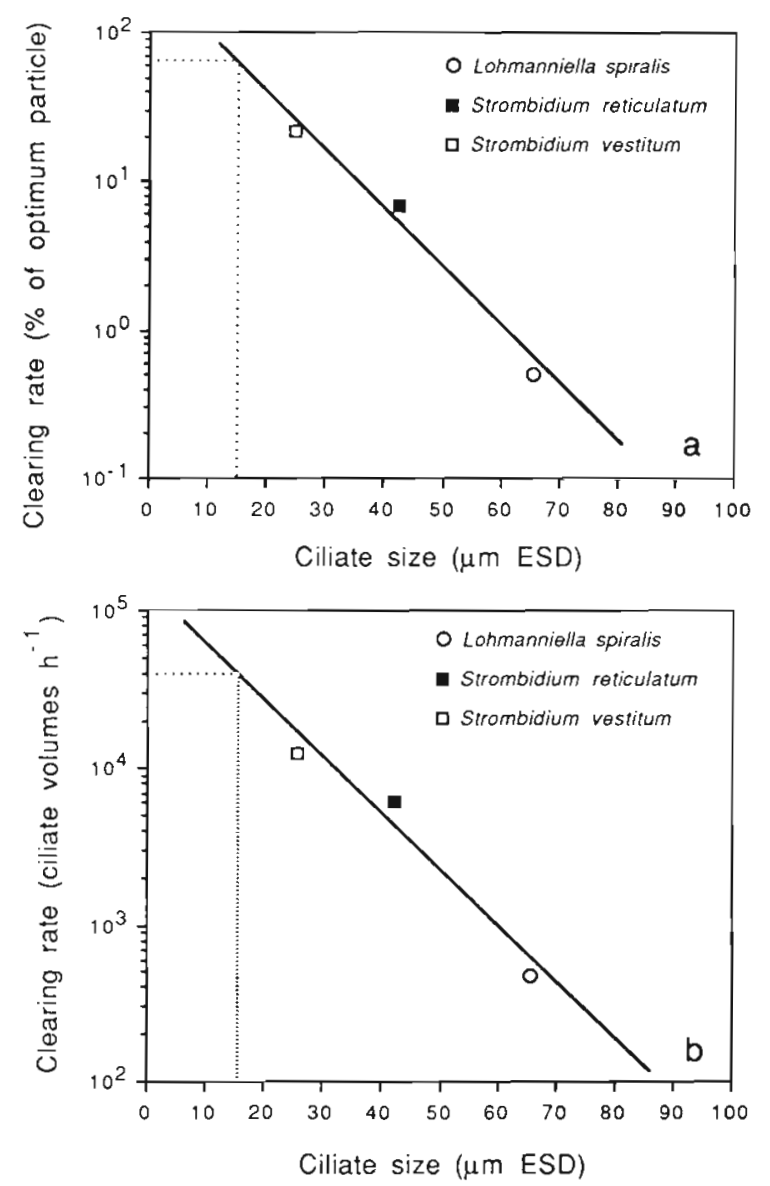

Fig. 10. (a) Ratio (\%) between clearing rate for $1.1 \mu \mathrm{m}$ beads and optimum particles as function of ciliate size (equivalent sphere diameter). The points are fitted to an exponential function which is extrapolated to a ciliate size of $15 \mu \mathrm{m}$ ESD. (b) Clearing rate (ciliate volumes $\mathrm{h}^{-1}$ ) for $1.1 \mu \mathrm{m}$ beads as function of ciliate size (equivalent sphere diameter). The points are fitted to an exponential function which is extrapolated to a ciliate size of $15 \mu \mathrm{m}$ ESD in oligotrophic seawater some inference from the clearing rates (Fig. 4) of Lohmanniella spiralis, $S$. reticulatum and $S$. vestitum can be made. In Fig. 10a the ratios of clearing rate for $1.1 \mu \mathrm{m}$ particles and optimum particles are plotted against ciliate size for the 3 studied ciliates. If extrapolated, this relation suggests that a hypothetical $15 \mu \mathrm{m}$ oligotrichous ciliate should retain $1.1 \mu \mathrm{m}$ at about $60 \%$ efficiency assuming $100 \%$ retention efficiency for optimum particle size. A similar extrapolation in Fig. 10b predicts that specific clearing rate (ciliate volumes $\mathrm{h}^{-1}$ ) for $1.1 \mu \mathrm{m}$ particles should increase for a small oligotrichous ciliate. This indicates that large bacteria and cyanobacteria may be efficiently cleared by small oligotrichous ciliates. However, average concentrations of bacteria and cyanobacteria in seawater seem too low to allow growth of even small oligotrichous ciliates. Assuming a clearing rate of $0.06 \mu \mathrm{l} \mathrm{h}^{-1}$ (from Fig. 10b) and a gross growth efficiency of $45 \%$ (from Fig. 9) a bacterial concentration of $1 \times 10^{5} \mu^{3} \mathrm{ml}^{-1}$ (Williams 1984) and a concentration of cyanobacteria of $5 \times 10^{4} \mu \mathrm{m}^{3} \mathrm{ml}^{-1}$ (Murphy \& Haugen 1985) give a growth rate of a hypothetical $15 \mu \mathrm{m}$ oligotrichous ciliate of only $0.002 \mathrm{~h}^{-1}$. This calculation is conservative since I have assumed that all bacteria are retained and that all assimilated energy is used for growth. The conclusion is that small oligotrichous ciliates either rely on patches with dense bacterial populations or that the diet is supplemented with small nanoplankton.

Results on gross growth efficiencies of oligotrichous ciliates and of heterotrophic flagellates growing on bacteria make it possible to calculate the fate of bacterial production in the water-column. If it is assumed that heterotrophic flagellates are major predators on bacteria and that oligotrichous ciliates prey on flagellates with gross growth efficiencies of $40 \%$ (Fenchel 1982 b) and $45 \%$ (Fig. 9) respectively, only $18 \%$ of the original bacterial production is available to larger zooplankton. Thus the protozoan links, heterotrophic flagellates and ciliates, may remineralize most of the bacterial production.

Acknowledgements. I thank Professor Tom Fenchel for constructive criticism and discussion. I am also grateful to all who assisted me at Tjärno Marine Biological Laboratory and at Rønbjerg Marine Biological Station. Finally I thank 2 anonymous referees for improvements of the manuscript. This work was supported by the Swedish Natural Science Research Council (NFR) through contract B-DT 1860-100.

\section{LITERATURE CITED}

Azam, F., Fenchel, T., Field, J. G., Gray, J. S., Meyer-Reil, L. A., Thingstad, F. (1983). The ecological role of watercolumn microbes in the sea. Mar. Ecol. Prog. Ser. 10: $257-263$ 
Beers, J. R., Stewart, G. L. (1969). Micro-zooplankton and its abundance relative to larger zooplankton and other seston components. Mar. Biol. 4: 182-189

Burkill, P. H. (1982). Ciliates and other microplankton components of a nearshore food-web: standing stocks and production processes. Ann. Inst. océanogr, Paris 58 (suppl.): 335-350

Børsheim, K. Y. (1984). Clearance rates of bacteria-sized particles by freshwater ciliates, measured with monodisperse fluorescent latex beads. Oecologia (Berl.) 63: 286-288

Calow, P. (1977). Conversion efficiencies in heterotrophic organisms. Biol. Rev. 52: 385-409

Conover, R. J. (1978). Transformation of organic matter. In: Kinne, O. (ed.) Marine ecology, Vol. IV, Dynamics. John Wiley \& Sons, Chichester, p. 221-499

Dale, T., Burkill, P. H. (1982). Live counting, a quick and simple technique for enumerating pelagic ciliates. Ann. Inst. océanogr., Paris 58 (suppl.): 267-276

Fenchel, T. (1980a). Suspension feeding in ciliated Protozoa: functional response and particle size selection. Microb. Ecol. 6: 1-11

Fenchel, T. (1980b). Suspension feeding in ciliated Protozoa: structure and function of feeding organelles. Arch. Protistenk. 123: 239-260

Fenchel, T. (1982a). Ecology of heterotrophic microflagellates. I. Some important forms and their functional morphology. Mar. Ecol. Prog. Ser. 8: 211-223

Fenchel, T. (1982b). Ecology of heterotrophic microflagellates. II. Bioenergetics and growth. Mar. Ecol. Prog. Ser. 8: 225-231

Fenchel, T. (1982c). Ecology of heterotrophic microflagellates. III. Adaptations to heterogeneous environments. Mar. Ecol. Prog. Ser. 9: 25-33

Fenchel, T. (1982d). Ecology of heterotrophic microflagellates. IV. Quantitative occurrence and importance as bacterial consumers. Mar. Ecol. Prog. Ser. 9: 35-42

Fenchel, T. (1986). Protozoan filter feeding. Prog. Protistology 1: in press

Fenchel, T., Finlay, B. J. (1983). Respiration rates in heterotrophic, free-living Protozoa. Microb. Ecol. 9: 99-122

Fuhrman, J. A., Azam, F. (1982). Thymidine incorporation as a measure of heterotrophic bacterioplankton production in marine surface waters: evaluation and field results. Mar Biol. 66: 109-120

Gifford, D. J. (1985). Laboratory culture of marine planktonic oligotrichs (Ciliophora, Oligotrichida), Mar Ecol. Prog. Ser. 23: 257-267

Grim, J. N., Halcrow, K. R. (1979). The oligotrich ciliate Strobilidium gyrans: its fresh-water environment, laboratory culture conditions, and stalking behavior. Trans. Am. micros. Soc. 98: 529-536

Guillard, R. R. L. (1975). Culture of phytoplankton for feeding marine invertebrates. In: Smith, W. L., Chanley, M. H. (ed.) Culture of marine invertebrate animals. Plenum Publ. Corp., New York, p. 29-60

Heinbokel, J. F. (1978a). Studies on the functional role of tintinnids in the Southern California Bight. I. Grazing and growth rates in laboratory cultures. Mar. Biol. 47: 177-189

Heinbokel, J. F. (1978b): Studies on the functional role of tintinnids in the Southern California Bight. II. Grazing rates of field populations. Mar Biol. 47: 191-197

Heinbokel, J. F., Beers, J. R. (1979). Studies on the functional role of tintinnids in the Southern Califormia Bight. III. Grazing impact of natural assemblages. Mar. Biol. 52: 23-32

Johnson, P. W., Sieburth, J. MCN. (1979). Chroococcoid cyanobacteria in the sea: a ubiquitous and diverse phototrophic biomass. Limnol. Oceanogr. 24: 928-935
Johnson, P. W., Sieburth, J. McN. (1982). In-situ morphology and occurrence of eucaryotic phototrophs of bacterial size in the picoplankton of estuarine and oceanic waters. J. Phycol. 18: 318-327

Kahl, A. (1932). Urtiere oder Protozoa. I. Wimpertiere oder Ciliata (Infusoria). 3. Spirotricha. In: Dahl, F. (ed) Die Tierwelt Deutschlands und der angrenzenden Meeresteile. Gustav Fischer Verlag, Jena

Klekowski, R. Z. (1981). Ecology of aquatic organisms. 3. Animals. Size dependence of metabolism on protozoans. Verh. int. Verein theor angew. Limnol. 21: 1498-1502

Larsson, U., Hagström, A. (1982). Fractionated phytoplankton primary production, exudate release and bacterial production in a Baltic eutrophication gradient. Mar. Biol. 67: $57-70$

Leegaard, C. (1915). Untersuchungen über einige Planktonciliaten des Meeres. Nyt Mag. Naturv. 53: 1-37

Lehninger, A. L. (1975). Biochemistry. Worth Publishers Inc., New York

Lessard, E. J., Swift, E. (1985). Species-specific grazing rates of heterotrophic dinoflagellates in oceanic waters, measured with a dual-label radioisotope technique. Mar. Biol. 87: $289-296$

Margalef, R. (1967). The food web in the pelagic environment. Helgoländer wiss. Meeresunters. 15: 548-559

Murphy, L. S., Haugen. E. M. (1985). The distribution and abundance of phototrophic ultraplankton in the North Atlantic. Limnol. Oceanogr. 30: 47-58

Nival, P., Nival, S. (1976). Particle retention efficiencies of an herbivorous copepod, Acartia clausi (adult and copepodite stages): effects on grazing. Limnol. Oceanogr. 21: 24-38

Rassoulzadegan, F. (1977). Évolution annuelle des ciliés pélagiques en Méditerranée nord-occidentale ciliés oligotriches 'non tintinnides' (Oligotrichina). Ann. Inst. océanogr., Paris 53: 125-134

Rassoulzadegan, F. (1982). Dependence of grazing rate, gross growth efficiency and food size range on temperature in a pelagic oligotrichous ciliate Lohmanniella spiralis Leeg., fed on naturally occurring particulate matter. Ann. Inst. océanogr., Paris 58: 177-184

Rassoulzadegan, F., Etienne, M. (1981). Grazing rate of the tintinnid Stenosemella ventricosa (Clap. \& Lachm.) Jörg. on the spectrum of the naturally occurring particulate matter from a Mediterranean neritic area. Limnol. Oceanogr 26: 258-270

Revelante, N., Gilmartin, M. (1983). Microzooplankton distribution in the Northerm Adriatic Sea with emphasis on the relative abundance of ciliated protozoans. Oceanologica Acta 6: 407-415

Scott, J. M. (1985). The feeding rates and efficiencies of a marine ciliate, Strombidium sp., grown under chemostat steady-state conditions. J. exp. mar Biol. Ecol. 90: 81-95

Sheldon, R. W., Nival, P., Rassoulzadegan, F. (1986). An experimental investigation of a flagellate-ciliate-copepod food chain with some observations relevant to the linear biomass hypothesis. Limnol. Oceanogr. 31: 184-188

Sherr, E. B., Sherr, B. F., Fallon, R. D., Newell, S. Y.(1986). Small, aloricate ciliates as major component of the marine heterotrophic nanoplankton. Limnol. Oceanogr. 31 $177-183$

Sieburth, J. McN. (1979). Sea microbes. Oxford Univ. Press, New York

Smetacek, V. (1981). The annual cycle of protozooplankton in the Kiel Bight. Mar. Biol. 63: 1-11

Spittler, P. (1973). Feeding experiments with tintinnids. Oikos 15 (suppl.): 128-132 
Stoecker, D. K. (1984). Particle production by planktonic ciliates. Limnol. Oceanogr. 29: 930-940

Stoecker, D. K., Davis, L. H., Provan, A. (1983). Growth of Favella sp. (Ciliata: Tintinnina) and other microzooplankters in cages incubated in situ and comparison to growth in vitro. Mar. Biol. 75: 293-302

Tuffrau, M. (1967). Perfectionnements et pratique de la technique d'imprégnation au protargol des infusoires ciliés. Protistologica 3: 91-98

Verity, P. G. (1985). Grazing, respiration, excretion, and growth rates of tintinnids. Limnol. Oceanogr. 30: 1268-1282

Watson, L. P., McKee, A. E., Merrell, B. R. (1980). Preparation of microbiological specimens for scanning electron microscopy. In: SEM/1980/II, SEM, Inc., AMF O'Hare, Chicago, p. 45-55

Williams, P. J. leB. (1984). Bacterial production in the marine food chain: The emperor's new suit of clothes? In: Fasham, M. J. R. (ed.) Flows of energy and materials in marine ecosystems. Plenum Press, New York, p. 271-299

This articie was presented by Professor T. Fenchel; it was accepted for printing on August 22, 1986 